\title{
Rhodococcus aetherivorans BCP1 as cell factory for the production of intracellular tellurium nanorods under aerobic conditions
}

\author{
Alessandro Presentato ${ }^{1 * \dagger}$, Elena Piacenza ${ }^{1 \dagger}$, Max Anikovskiy ${ }^{2}$, Martina Cappelletti ${ }^{3}$, Davide Zannoni ${ }^{3}$ \\ and Raymond J. Turner ${ }^{1 *}$
}

\begin{abstract}
Background: Tellurite $\left(\mathrm{TeO}_{3}{ }^{2-}\right)$ is recognized as a toxic oxyanion to living organisms. However, mainly anaerobic or facultative-anaerobic microorganisms are able to tolerate and convert $\mathrm{TeO}_{3}{ }^{2-}$ into the less toxic and available form of elemental Tellurium $\left(\mathrm{Te}^{0}\right.$ ), producing Te-deposits or Te-nanostructures. The use of $\mathrm{TeO}_{3}{ }^{2-}$-reducing bacteria can lead to the decontamination of polluted environments and the development of "green-synthesis" methods for the production of nanomaterials. In this study, the tolerance and the consumption of $\mathrm{TeO}_{3}{ }^{2-}$ have been investigated, along with the production and characterization of Te-nanorods by Rhodococcus aetherivorans BCP1 grown under aerobic conditions.
\end{abstract}

Results: Aerobically grown $\mathrm{BCP} 1$ cells showed high tolerance towards $\mathrm{TeO}_{3}{ }^{2-}$ with a minimal inhibitory concentration (MIC) of $2800 \mu \mathrm{g} / \mathrm{mL}\left(11.2 \mathrm{mM}\right.$ ). $\mathrm{TeO}_{3}{ }^{2-}$ consumption has been evaluated exposing the BCP1 strain to either 100 or $500 \mu \mathrm{g} / \mathrm{mL}$ of $\mathrm{K}_{2} \mathrm{TeO}_{3}$ (unconditioned growth) or after re-inoculation in fresh medium with new addition of $\mathrm{K}_{2} \mathrm{TeO}_{3}$ (conditioned growth). A complete consumption of $\mathrm{TeO}_{3}{ }^{2-}$ at $100 \mu \mathrm{g} / \mathrm{mL}$ was observed under both growth conditions, although conditioned cells showed higher consumption rate. Unconditioned and conditioned BCP1 cells partially consumed $\mathrm{TeO}_{3}{ }^{2-}$ at $500 \mathrm{\mu g} / \mathrm{mL}$. However, a greater $\mathrm{TeO}_{3}{ }^{2-}$ consumption was observed with conditioned cells. The production of intracellular, not aggregated and rod-shaped Te-nanostructures (TeNRs) was observed as a consequence of $\mathrm{TeO}_{3}{ }^{2-}$ reduction. Extracted TeNRs appear to be embedded in an organic surrounding material, as suggested by the chemical-physical characterization. Moreover, we observed longer TeNRs depending on either the concentration of precursor ( 100 or $500 \mathrm{\mu g} / \mathrm{mL}$ of $\mathrm{K}_{2} \mathrm{TeO}_{3}$ ) or the growth conditions (unconditioned or conditioned grown cells).

Conclusions: Rhodococcus aetherivorans $\mathrm{BCP} 1$ is able to tolerate high concentrations of $\mathrm{TeO}_{3}{ }^{2-}$ during its growth under aerobic conditions. Moreover, compared to unconditioned $\mathrm{BCP} 1$ cells, $\mathrm{TeO}_{3}{ }^{2-}$ conditioned cells showed a higher

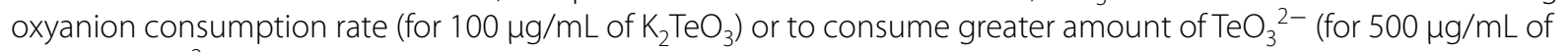
$\mathrm{K}_{2} \mathrm{TeO}_{3}$ ). $\mathrm{TeO}_{3}{ }^{2-}$ consumption by $\mathrm{BCP} 1$ cells led to the production of intracellular and not aggregated TeNRs embedded in an organic surrounding material. The high resistance of $\mathrm{BCP} 1$ to $\mathrm{TeO}_{3}{ }^{2-}$ along with its ability to produce Tenanostructures supports the application of this microorganism as a possible eco-friendly nanofactory.

Keywords: Tellurite, Rhodococcus aetherivorans, Elemental tellurium, Tellurium nanorods, Biogenic nanostructures, Nanorods biosynthesis

\footnotetext{
*Correspondence: alessandro.presentat@ucalgary.ca;

turnerr@ucalgary.ca

${ }^{\dagger}$ Alessandro Presentato and Elena Piacenza contributed equally to this

work

${ }^{1}$ Microbial Biochemistry Laboratory, Department of Biological Sciences,

University of Calgary, 2500 University Dr. NW, Calgary, AB T2N 1N4,

Canada

Full list of author information is available at the end of the article
} 


\section{Background}

Tellurium (Te) was discovered by Franz-Joseph Müller von Reicheinstein in 1782 [1], and in nature this element can be found in gold ores as association with metals, forming calaverite $\left(\mathrm{AuTe}_{2}\right)$, sylvanite $\left(\mathrm{AgAuTe}_{4}\right)$ and nagyagite $\left[\mathrm{AuPb}(\mathrm{Sb}, \mathrm{Bi}) \mathrm{Te}_{2-3} \mathrm{~S}_{6}\right]$ [2]. Te is an element of the chalcogen family, belonging to the Group 16 of the periodic table along with oxygen $(\mathrm{O})$, sulfur $(\mathrm{S})$, selenium (Se), and the radioactive element polonium (Po) [3]. Additionally, it is defined as a metalloid due to its intermediate properties between metals and non-metals [3]. Due to the anthropogenic activity, $\mathrm{Te}$ is normally present in the environment as inorganic telluride $\left(\mathrm{Te}_{2}\right)$, the oxyanions tellurite $\left(\mathrm{TeO}_{3}{ }^{2-}\right)$ and tellurate $\left(\mathrm{TeO}_{4}{ }^{2-}\right)$, and the organic dimethyl telluride $\left(\mathrm{CH}_{3} \mathrm{TeCH}_{3}\right)$ [4]. Among these, $\mathrm{TeO}_{3}{ }^{2-}$ is the most soluble form of tellurium, and it is the most toxic form for both prokaryotes and eukaryotes [5] at concentrations as low as $1 \mu \mathrm{g} / \mathrm{mL}$ [6]. This concentration is several orders of magnitude lower as compared to others metals and metalloids of public health and environmental concern such as selenium, iron, mercury, cadmium, copper, chromium, zinc, and cobalt [7, 8]. Furthermore, due to tellurite's use in electronics as well as industrial glasses, it can be found highly concentrated in soil and water near waste discharge sites of manufacturing and processing facilities [9], as a hazardous and toxic pollutant [6]. Despite $\mathrm{TeO}_{3}{ }^{2-}$ toxicity, several Gram-negative microorganisms capable to grow phototrophycally or chemotrophycally under aerobic and anaerobic conditions have been described for their capability to reduce this toxic oxyanion, such as Rhodobacter capsulatus B100, Shewanella odeinensis MR-1, Pseudomonas pseudoalcaligenes KF707, and Escherichia coli HB101 strain [10-13]. Additionally, $\alpha$-Proteobacteria resistant to concentrations of $\mathrm{TeO}_{3}{ }^{2-}$ ranging from 1 to $25 \mathrm{mg} / \mathrm{mL}$ [14, 15] and a few Gram-positive strains (e.g., Bacillus beveridgei sp.nov., Bacillus selenitireducens, Corynebacterium diphtheria, Lysinibacillus sp. ZYM-1, Bacillus sp. BZ, Bacillus sp. STG-83, Paenibacillus TeW, and Salinicoccus sp. QW6) resistant to low level of $\mathrm{TeO}_{3}{ }^{2-}$ (ranging from 0.2 to $3 \mathrm{mg} / \mathrm{mL}$ ) were also reported [16-23].

It has been established that $\mathrm{TeO}_{3}{ }^{2-}$-reducing bacteria are able to convert this oxyanion to the less toxic elemental tellurium $\left(\mathrm{Te}^{0}\right)$, which is cytosolically accumulated as black inclusions [6] and/or defined nanostructures such as nanocrystals, nanorods (NRs) and nanoparticles (NPs) [24]. Particularly, Kim and colleagues [25] showed the capability of Shewanella oneidensis MR-1 to produce tellurium nanorods (TeNRs), while Rhodobacter capsulatus B100 is able to produce both intra- and extra-cellular needle-shaped Te-nanocrystals [10]. Another example is the synthesis of tellurium nanoparticles (TeNPs) in cells of Ochrobactrum MPV-1 [26].
NPs and NRs have different physical-chemical and biological properties compared to their bulk counterparts, due to their size, high surface-volume ratio, large surface energy and spatial confinement, allowing the use of these nanostructures in biomedical, electronic, environmental, and renewable energy fields, to name a few [24]. In this context, the natural ability of microorganisms to generate nanostructures by the reduction of toxic oxyanions can play two key roles: (1) the development of eco-friendly "greensynthesis" methods for the production of NPs or NRs [27], and (2) the decontamination of metal polluted environments [28]. Moreover, the biological synthesis of either NPs or NRs has several advantages over the chemical one, namely: (1) it does not require the use of toxic chemicals; (2) it does not result in the formation of hazardous wastes; and (3) it has a substantial lower cost of production [29].

Strains of the Rhodococcus genus, belonging to the Mycolata group of Actinomycetes, are aerobic non-sporulating bacteria, which are ideal microorganisms for bioremediation and industrial uses due to their remarkable capacity to catalyze a very wide range of compounds and their environmental robustness [30]. Although the ability of Rhodococcus spp. to degrade xenobiotics along with their physiological adaptation strategies, i.e. cell membrane composition and intracellular inclusions, were largely reported in the literature [31], much less is known about the Rhodococcus genus capacity to resist to toxic metals/metalloids. In this respect, Rhodococcus aetherivorans $\mathrm{BCP} 1$, a hydrocarbon- and chlorinated solvent degrader that was recently described for its unique capacity to overcome stress environmental conditions in the presence of a wide range of antimicrobials and toxic metals/metalloids such as tellurite, arsenate and selenite [32-36] appears to be an interesting candidate to study. Thus, the present work investigates the ability of Rhodococcus aetherivorans $\mathrm{BCP} 1$ to survive in the presence of increasing concentrations of tellurite and to produce Tenanostructures. In particular, we evaluated the capacity of BCP1 strain to grow in the presence of high concentrations of $\mathrm{TeO}_{3}{ }^{2-}$ oxyanions supplied as $\mathrm{K}_{2} \mathrm{TeO}_{3}$. $\mathrm{TeO}_{3}{ }^{2-}$ consumption rates were also assessed after re-inoculation of pre-exposed cells in fresh medium with new addition of $\mathrm{K}_{2} \mathrm{TeO}_{3}$ (conditioned cells). Finally, the production of Te-nanostructures was investigated through the use of physical-chemical methods.

\section{Methods}

\section{Bacterial strain, growth media, culture conditions}

The strain Rhodococcus aetherivorans BCP1 (DSM 44980) was pre-cultured in $250 \mathrm{~mL}$ Erlenmeyer Baffled Flask for 2 days, containing $25 \mathrm{~mL}$ of Luria-Bertani medium (here indicated as LB) [composed of $(\mathrm{g} / \mathrm{L}) \mathrm{NaCl}, 10$; Yeast Extract, 5; Tryptone, 10]. When necessary, the medium 
was solidified by adding $15 \mathrm{~g} / \mathrm{L}$ of Agar. BCP1 cells were then inoculated $(1 \% \mathrm{v} / \mathrm{v})$ and grown for 5 days in $50 \mathrm{~mL}$ of LB medium supplied with either $100(0.4 \mathrm{mM})$ or 500 (2 mM) $\mu \mathrm{g} / \mathrm{mL}$ of $\mathrm{K}_{2} \mathrm{TeO}_{3}$. Here we refer to this first bacterial growth as unconditioned. After this growth step, BCP1 cells were re-inoculated $(1 \% \mathrm{v} / \mathrm{v})$ and cultured for other 5 days in $50 \mathrm{~mL}$ of fresh LB medium and 100 or $500 \mu \mathrm{g} / \mathrm{mL}$ of $\mathrm{K}_{2} \mathrm{TeO}_{3}$. This secondary bacterial growth is here defined as conditioned. Each culture was incubated aerobically at $30{ }^{\circ} \mathrm{C}$ with shaking $(150 \mathrm{rpm})$. In order to evaluate the bacterial growth rate, every $24 \mathrm{~h}$ an aliquot $(100 \mu \mathrm{L})$ of $\mathrm{BCP} 1$ cells was collected from each culture and serially diluted in sterile saline solution $(\mathrm{NaCl} 0.9 \% \mathrm{w} / \mathrm{v})$. The cells were recovered on LB agar plates for $48 \mathrm{~h}$ at $30{ }^{\circ} \mathrm{C}$. The number of growing cells is reported as average of the Colony Forming Unit per milliliter (CFU/mL) counted for each biological trial $(\mathrm{n}=3)$ with standard deviation. All the reagents were purchased from Sigma-Aldrich ${ }^{\circledR}$.

\section{Evaluation of $\mathrm{TeO}_{3}{ }^{2-}$ minimal inhibitory concentration (MIC)}

In order to establish the minimal inhibitory concentration (MIC) of tellurite, i.e. as the concentration of $\mathrm{K}_{2} \mathrm{TeO}_{3}$ at which no bacterial growth was observed, the $\mathrm{BCP} 1$ strain was exposed to concentrations of $\mathrm{K}_{2} \mathrm{TeO}_{3}$ ranging from 100 to $3000 \mu \mathrm{g} / \mathrm{mL}(0.4-12 \mathrm{mM})$. After $24 \mathrm{~h}$ of incubation the number of viable cells was determined by spot plates count on LB agar recovery plates. The assay was conducted in triplicate and the data are reported as average of the CFU/mL counted with standard deviation. The established MIC and corresponding kill curve was used to choose the best concentration of $\mathrm{K}_{2} \mathrm{TeO}_{3}$ to use for nano-material production.

\section{$\mathrm{TeO}_{3}{ }^{2-}$ consumption assay}

The residual concentration of $\mathrm{TeO}_{3}{ }^{2-}$ oxyanions in the culture broth was estimated as described elsewhere [37]. Briefly, $1 \mathrm{~mL}$ of BCP1 cells grown as unconditioned or conditioned in the presence of $\mathrm{K}_{2} \mathrm{TeO}_{3}$ was collected every 12 up to $120 \mathrm{~h}$. The sample was centrifuged at $14,000 \mathrm{rpm}$ for $2 \mathrm{~min}$ in order to separate the bacterial cell pellet from the supernatant, and a $10-100 \mu \mathrm{L}$ aliquot was mixed with $600 \mu \mathrm{L}$ of $0.5 \mathrm{M}$ Tris- $\mathrm{HCl}$ buffer $\mathrm{pH}$ $7.0\left(\mathrm{VWR}^{\circledR}\right.$ ), $200 \mu \mathrm{L}$ of diethyldithiocarbamate (SigmaAldrich $^{\circledR}$ ), and LB up to a total volume of $1 \mathrm{~mL}$. The absorbance of the mixture was read at $340 \mathrm{~nm}$ using a Varian Cary ${ }^{\circledR} 50$ Bio UV-Visible Spectrophotometer. The residual concentration of $\mathrm{TeO}_{3}{ }^{2-}$ oxyanions was determined using this absorbance values and the calibration curve obtained for known concentrations $(0,10,20,30$, $40,50$ and $60 \mu \mathrm{g} / \mathrm{mL})$ of $\mathrm{K}_{2} \mathrm{TeO}_{3}$ in $\mathrm{LB}\left(\mathrm{R}^{2}=0.99\right)$. The data are reported as average values $(\mathrm{n}=3)$ with standard deviation.

\section{Preparation, extraction, and purification of TeNRs}

In order to extract and purify TeNRs produced by the BCP1 strain grown as unconditioned or conditioned cells, biomasses were collected by centrifugation (3700 rpm) for 20 min after 5 culturing days. The pellets were washed twice with saline solution $(\mathrm{NaCl} 0.9 \% \mathrm{w} / \mathrm{v})$ and resuspended in Tris- $\mathrm{HCl}(1.5 \mathrm{mM})$ buffer $\mathrm{pH}$ 7.4. Bacterial cells were disrupted by ultrasonication at $22 \mathrm{~W}$ for $10 \mathrm{~min}$ (30 s burst interspersed by $30 \mathrm{~s}$ of pause) on ice (MICROSON $^{\mathrm{TM}}$ Ultrasonic Cell Disruptor XL, Qsonica Misonix Inc.). The cellular debris was then separated from TeNRs in the supernatant by a centrifugation step (3700 rpm) for $20 \mathrm{~min}$. Supernatants containing TeNRs were incubated overnight $(16 \mathrm{~h})$ at $4{ }^{\circ} \mathrm{C}$ with 1 -Octanol $\left(\right.$ Sigma-Aldrich $\left.{ }^{\circledR}\right)$ in a ratio 4:1 $(\mathrm{v} / \mathrm{v})$ and then recovered by centrifugation $(16,000 \mathrm{rpm})$ for $15 \mathrm{~min}$. TeNRs pellets were finally suspended in deionized water.

Here we refer to the TeNRs produced by the BCP1 strain as $\mathrm{TeNRs}_{100}$ or $\mathrm{TeNRs}_{500}$, depending on the initial concentration of $\mathrm{K}_{2} \mathrm{TeO}_{3}$ present in the growth medium.

\section{Dynamic light scattering (DLS) and zeta potential measurements}

DLS and zeta potential measurements of TeNRs produced by BCP1 cells grown as unconditioned or conditioned were performed using a Zen 3600 Zetasizer Nano $\mathrm{ZS}^{\mathrm{TM}}$ from Malvern Instruments. The samples $(1 \mathrm{~mL}$ each) were analyzed in a spectrophotometric cuvette $(10 \times 10 \times 45 \mathrm{~mm}$ Acrylic Cuvettes, Sarstedt $)$ and in a folded capillary Zeta cell (Malvern Instruments) for DLS and zeta potential measurements, respectively.

\section{Transmission electron microscopy (TEM) analysis}

TEM observations of TeNRs extracted from BCP1 cells grown as unconditioned or conditioned were carried out by mounting $5 \mu \mathrm{L}$ of each sample on carbon-coated copper grids (CF300-CU, Electron Microscopy Sciences), air-drying the samples, and imaging them using a Hitachi H7650 TEM. The distribution of TeNRs length was calculated by measuring the length of 100 randomly chosen nanorods through the use of ImageJ software. The distribution was fitted to a Gaussian function to yield the average length. In order to image $\mathrm{BCP} 1$ cells grown in the presence of 100 or $500 \mu \mathrm{g} / \mathrm{mL} \mathrm{K}_{2} \mathrm{TeO}_{3}$ for 5 days, the cells were negatively stained using a $1 \%$ phosphotungstic acid solution ( $\mathrm{pH} 7.3)$.

\section{Scanning electron microscopy (SEM) and energy-dispersed $\mathrm{X}$-ray spectroscopy (EDX) analysis}

The samples were prepared by depositing TeNRs suspensions onto Crystal Silicon wafers (type N/Phos, size $100 \mathrm{~mm}$, University Wafer) and air-drying. Imaging and EDX analysis were performed on a Zeiss Sigma VP 
scanning electron microscope and an Oxford Instruments INCAx-act system, respectively.

\section{Results}

Minimal inhibitory concentration (MIC) assay of Rhodococcus sp. BCP1 strain

In order to evaluate the $\mathrm{BCP} 1$ strain's ability to tolerate $\mathrm{TeO}_{3}{ }^{2-}$ oxyanions present in the growth medium (LB), the MIC was established by exposing the cells for $24 \mathrm{~h}$ to different $\mathrm{K}_{2} \mathrm{TeO}_{3}$ concentrations, ranging from 0 to $3000 \mu \mathrm{g} / \mathrm{mL}(0-12 \mathrm{mM})$. The data are plotted in Fig. 1 as a kill curve displaying the number of $\mathrm{BCP} 1$ viable cells against the $\mathrm{K}_{2} \mathrm{TeO}_{3}$ concentration values. As a result, the MIC value of $\mathrm{TeO}_{3}{ }^{2-}$ was estimated at $2800 \mu \mathrm{g} / \mathrm{mL}$ $(11.2 \mathrm{mM})$ that corresponded to $3 \log$ reduction as compared to the number of viable cells counted at the time of inoculation, while only 1 and $2 \log$ reduction of BCP1 viable cells was observed when the $\mathrm{K}_{2} \mathrm{TeO}_{3}$ was varied from 100 to $1000 \mu \mathrm{g} / \mathrm{mL}(0.4-4 \mathrm{mM})$ and from 100 to $2000 \mu \mathrm{g} / \mathrm{mL}(0.4-8 \mathrm{mM})$, respectively.

\section{Growth and consumption of $\mathrm{TeO}_{3}{ }^{2-}$ by the $\mathrm{BCP} 1$ strain, and localization of TeNRs}

Since the number of BCP1 viable cells decreased by less than $1 \log$ after $24 \mathrm{~h}$ exposure to $100 \mu \mathrm{g} / \mathrm{mL}\left(5.00 \times 10^{5}\right.$ $\mathrm{CFU} / \mathrm{mL})$ or $500 \mu \mathrm{g} / \mathrm{mL}\left(1.00 \times 10^{5} \mathrm{CFU} / \mathrm{mL}\right)$ of $\mathrm{K}_{2} \mathrm{TeO}_{3}$, the growth and consumption of $\mathrm{TeO}_{3}{ }^{2-}$ at these concentrations by the BCP1 strain were evaluated for both unconditioned and conditioned grown cells (Fig. 2). Unconditioned $\mathrm{BCP} 1$ cells grown in the presence of $100 \mu \mathrm{g} / \mathrm{mL}$ of $\mathrm{K}_{2} \mathrm{TeO}_{3}$ showed an initial consumption of the oxyanions during their lag phase $(24 \mathrm{~h})$, while a complete reduction occurred in the early exponential growth phase $(48 \mathrm{~h})$, showing a stationary phase after $60 \mathrm{~h}$ of growth (Fig. 2a). In the case of conditioned $\mathrm{BCP} 1$ cells the reduction of the same amount of $\mathrm{TeO}_{3}{ }^{2-}$ was $12 \mathrm{~h}$ faster $(36 \mathrm{~h})$ as compared to those grown as unconditioned, occurring in the early exponential growth phase. As for unconditioned cells, the conditioned ones

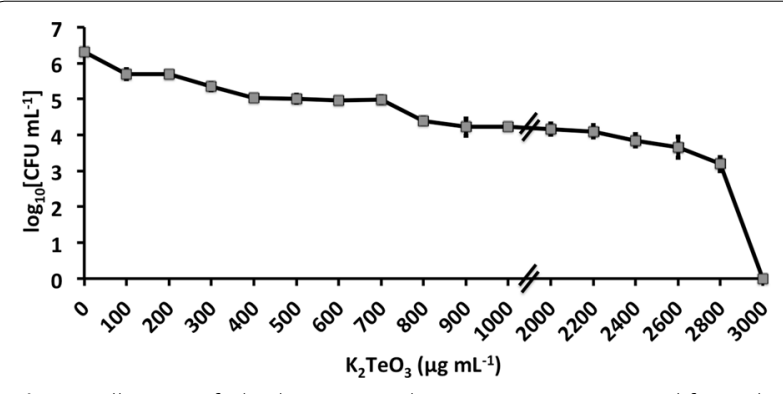

Fig. 1 Kill curve of Rhodococcus aetherivorans BCP1 exposed for $24 \mathrm{~h}$ to increasing concentration of $\mathrm{K}_{2} \mathrm{TeO}_{3}$, with the established minimal inhibitory concentration (MIC) reached the stationary phase after $60 \mathrm{~h}$ of incubation and any lag phase of growth was observed (Fig. 2b). By contrast, considering unconditioned $\mathrm{BCP} 1$ cells growing in the presence of $500 \mu \mathrm{g} / \mathrm{mL}$ of $\mathrm{K}_{2} \mathrm{TeO}_{3}$, the consumption/reduction of the oxyanions was not complete over the incubation time $(120 \mathrm{~h})$, resulting in the reduction of about $45 \%(218 \mu \mathrm{g})$ of the initial amount of $\mathrm{TeO}_{3}{ }^{2-}$ (Fig. 2c). Particularly, the initial amount of the oxyanions decreased by $153 \mu \mathrm{g}$ during the lag phase of growth $(24 \mathrm{~h})$, reaching the maximum extent of reduction after $72 \mathrm{~h}$ of incubation $(282 \mu \mathrm{g})$, and it remained constant over the stationary growth phases (Fig. 2c). Regarding conditioned $\mathrm{BCP} 1 \mathrm{~K}_{2} \mathrm{TeO}_{3}$-grown cells in the presence of $500 \mu \mathrm{g} / \mathrm{mL}$, we did not observe a complete reduction of the initial $\mathrm{TeO}_{3}{ }^{2-}$ concentration, although the amount of residual oxyanions present in the medium was lower $(152 \mu \mathrm{g})$ as compared to unconditioned grown cells. Specifically, a reduction of $56 \mu \mathrm{g}$ of $\mathrm{TeO}_{3}{ }^{2-}$ oxyanions during the initial $36 \mathrm{~h}$ of incubation was observed, which corresponds to the lag phase of growth, while after $84 \mathrm{~h}$ $\mathrm{TeO}_{3}{ }^{2-}$ oxyanions concentration dropped down to its minimal value, along with an actual growth of the biomass (Fig. 2d).

To detect the production of tellurium nanostructures by $\mathrm{BCP} 1$, either 100 or $500 \mu \mathrm{g} / \mathrm{mL} \mathrm{K}_{2} \mathrm{TeO}_{3}$-grown cells for 5 days were negatively stained and analyzed by TEM (Fig. 3). In both cases, the presence of intracellular TeNRs was detected (Fig. 3a, b).

\section{Dynamic light scattering (DLS) analyses}

DLS experiments were performed on TeNRs extracted from BCP1 unconditioned and conditioned grown cells (Additional file 1: Figure S1). The measurements yielded distributions of sizes centered at $295 \mathrm{~nm}$ (Additional file 1: Figure S1a, b) for the samples of TeNRs ${ }_{100}$ produced by $\mathrm{BCP} 1$ strain grown as unconditioned or conditioned cells, with a standard deviation of $\pm 61 \mathrm{~nm}$ (unconditioned) and $\pm 22 \mathrm{~nm}$ (conditioned). TeNRs $\mathrm{s}_{500}$ isolated from unconditioned and conditioned grown cells were featured by a size distribution centered at $342 \mathrm{~nm}$ (Additional file 1: Figure S1c, d), with a standard deviation of \pm 64 and $\pm 86 \mathrm{~nm}$, respectively. The TeNRs populations were found to be polydisperse as indicated by the values of the measured polydispersity index, being $0.398\left(\mathrm{TeNRs}_{100}\right)$ and $0.395\left(\mathrm{TeNRs}_{500}\right)$ for Te-nanostructures generated by unconditioned BCP1 cells, and 0.384 $\left(\mathrm{TeNRs}_{100}\right)$ and $0.381\left(\mathrm{TeNRs}_{500}\right)$ for those isolated from conditioned cells. Additional DLS experiments were performed on the supernatants containing TeNRs, which were recovered by removing TeNRs from the samples through centrifugation at $8000 \mathrm{rpm}$ for $10 \mathrm{~min}$. The DLS measurements performed on the supernatants (Additional file 1: Figure S2) produced distributions shifted 

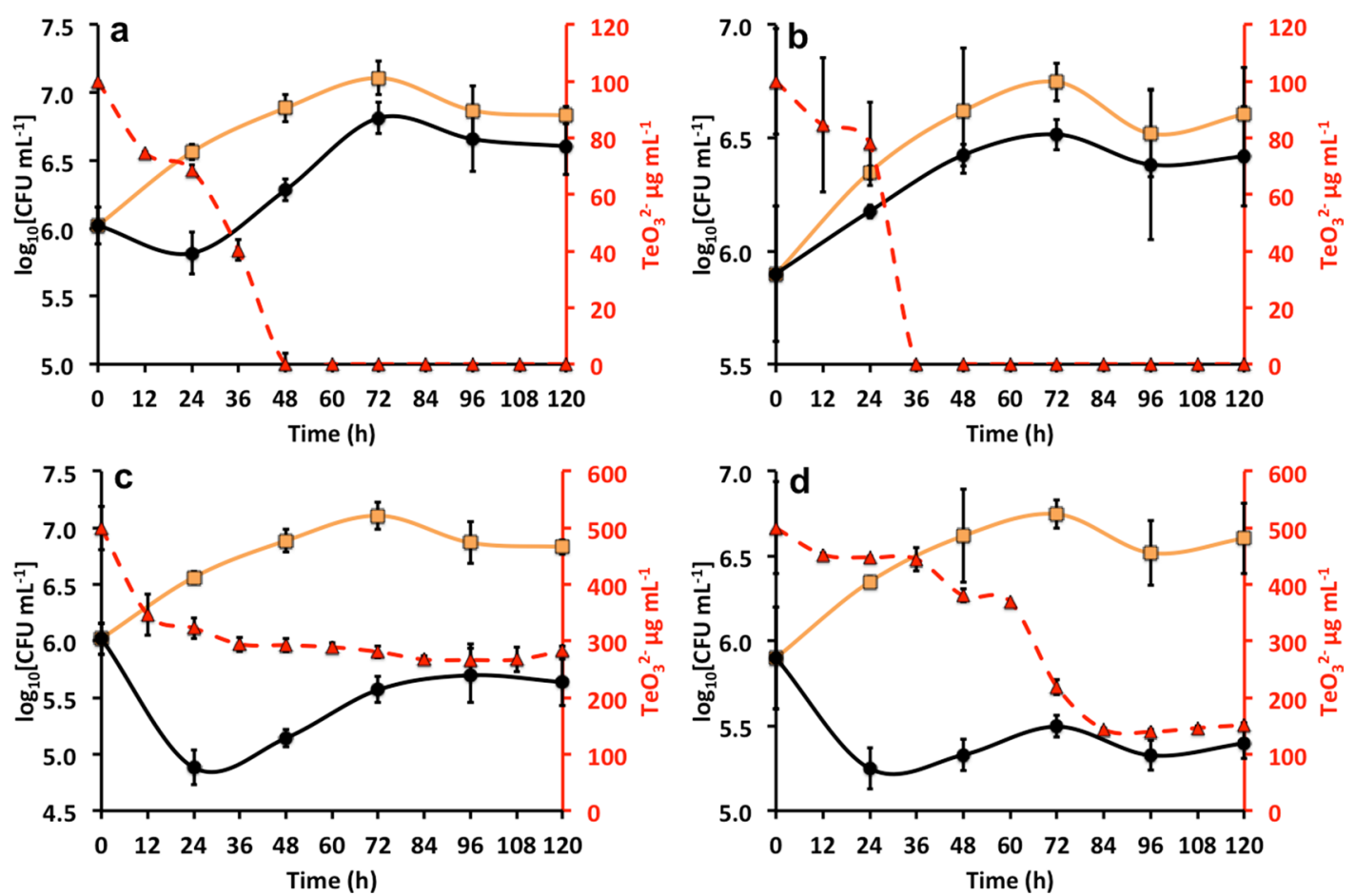

Fig. 2 Rhodococcus aetherivorans BCP1 growth in $\square$ LB medium, conditioned (b, d) cells, and $\triangle-\mathrm{TeO}_{3}{ }^{2-}$ consumption

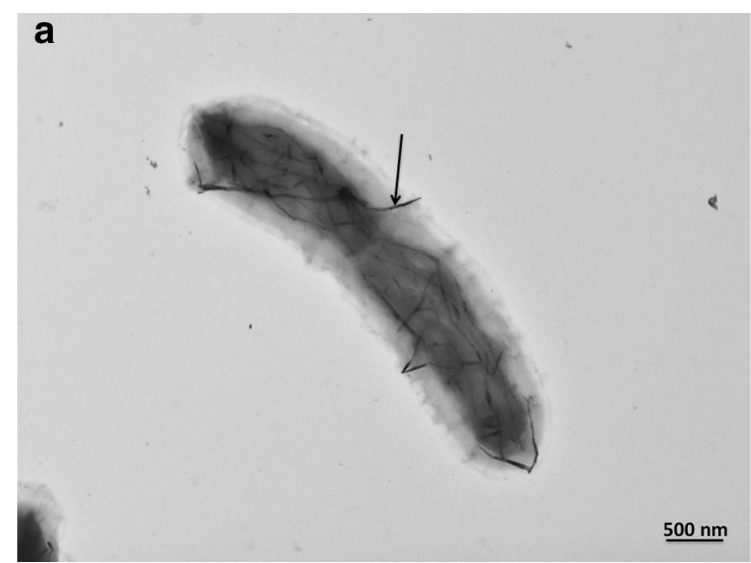

b

B supplied with 100 or $500 \mu \mathrm{g} / \mathrm{mL}$ of $\mathrm{K}_{2} \mathrm{TeO}_{3}$ as unconditioned $(\mathbf{a}, \mathbf{c})$ or

Fig. 3 Transmission electron microscopy (TEM) micrographs of BCP1 cells grown for $120 \mathrm{~h}$ in the presence of $100 \mu \mathrm{g} / \mathrm{mL}(\mathbf{a})$, and $500 \mu \mathrm{g} / \mathrm{mL}(\mathbf{b})$ of $\mathrm{K}_{2} \mathrm{TeO}_{3}$. Arrows indicate the intracellular TeNRs produced by the $\mathrm{BCP} 1$ strain

towards smaller sizes compared to the ones obtained from the samples containing the nanorods (Additional file 1: Figure S1): $142 \pm 14$ and $164 \pm 9 \mathrm{~nm}$ (Additional file 1: Figure S2a, b) for the supernatants recovered after removing TeNRs $s_{100}$ produced by BCP1 grown as unconditioned or conditioned cells, and $142 \pm 17$ and $122 \pm 12 \mathrm{~nm}$ (Additional file 1: Figure S2c, d) for the supernatants obtained after removing $\mathrm{TeNRs}_{500}$ generated by the cells grown as unconditioned or conditioned, respectively. As a control, DLS analysis of the supernatant derived from the BCP1 culture grown for $120 \mathrm{~h}$ on rich medium (LB) showed a peak centered at $1 \pm 0.48 \mathrm{~nm}$ (Additional file 1: Figure S2e), which is likely due to the presence of peptides in the culture broth. 


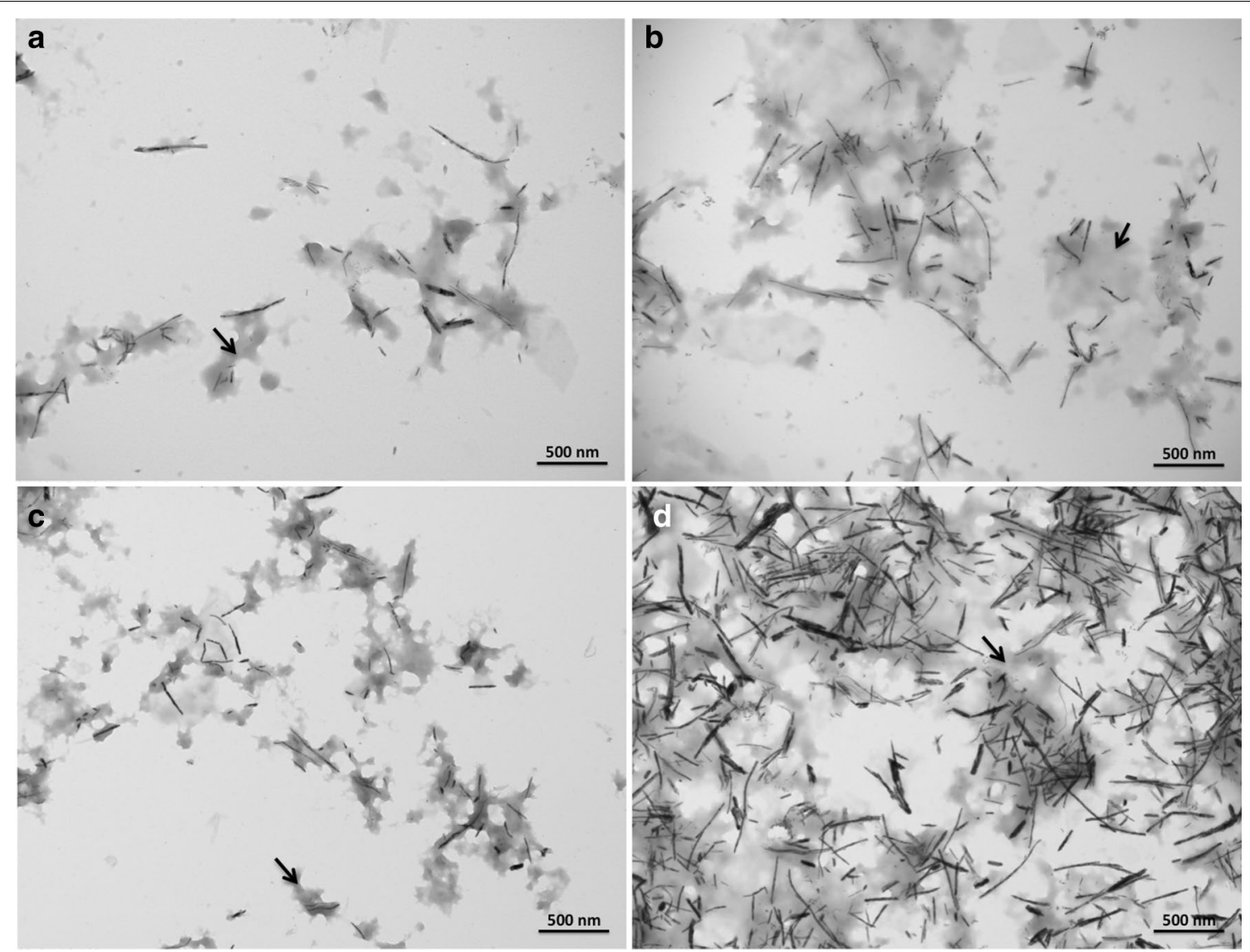

Fig. 4 Transmission electron microscopy (TEM) micrographs of TeNRs ${ }_{100}(\mathbf{a})$, and TeNRs $s_{500}(\mathbf{b})$ extracted from the BCP1 strain grown as unconditioned cells in the presence of $\mathrm{K}_{2} \mathrm{TeO}_{3}$, and TeNRs ${ }_{100}(\mathbf{c})$, and TeNRs ${ }_{500}(\mathbf{d})$ recovered from those conditioned

\section{Transmission electron microscopy (TEM) analysis and size distribution of TeNRs}

TEM observations were carried out on extracted TeNRs in order to study the size and morphology of TeNRs produced by both unconditioned and conditioned cells (Fig. 4). TeNRs from unconditioned cells revealed the presence of electron-dense and not aggregated NRs showing variability in length (Fig. 4a, b). Particularly, the length measurements using ImageJ software of 100 randomly chosen NRs yielded an average size of $148 \pm 104$ and $223 \pm 116 \mathrm{~nm}$ for TeNRs ${ }_{100}$ and $\mathrm{TeNRs}_{500}$, respectively (Fig. 5a, b). High electron-density was observed in TeNRs extracted from conditioned cells as well (Fig. 4c, d). TeNRs ${ }_{100}$ or TeNRs ${ }_{500}$ isolated from BCP1 conditioned cells were longer compared to those generated by unconditioned cells, with a broader length distribution. In this case, the evaluated average size of NRs is $354 \pm 125$ and $463 \pm 147 \mathrm{~nm}$ for $\mathrm{TeNRs}_{100}$ and $\mathrm{TeNRs}_{500}$, respectively (Fig. 5c, d). Furthermore, the TEM analyses of TeNRs extracted from either unconditioned or conditioned cells revealed the presence of an electron-dense material surrounding the nanorods (Fig. 4, indicated by arrows).

\section{Zeta potential measurement}

Zeta potential measurements were conducted to evaluate whether the surface of TeNRs was charged (Additional file 1: Figure S3). A single peak at $-25 \mathrm{mV}$ was detected in Zeta potential plots for both unconditioned generated TeNRs $_{100}$ and TeNRs ${ }_{500}$ (Additional file 1: Figure S3a, b). The zeta potential results obtained for TeNRs produced by conditioned BCP1 cells indicated the presence of a less negative potential $(-20 \mathrm{mV})$ in the case of TeNRs $\mathrm{s}_{100}$, while TeNRs $s_{500}$ were featured by the same potential value of unconditioned NRs $(-25 \mathrm{mV})$ (Additional file 1: Figure S3c, d). Similarly to the DLS analysis, additional zeta potential measurements were performed on the supernatants recovered after removing TeNRs through centrifugation (Additional file 1: Figure S4), resulting in similar surface potential values as compared to those obtained for TeNRs suspensions. Particularly, the supernatants 

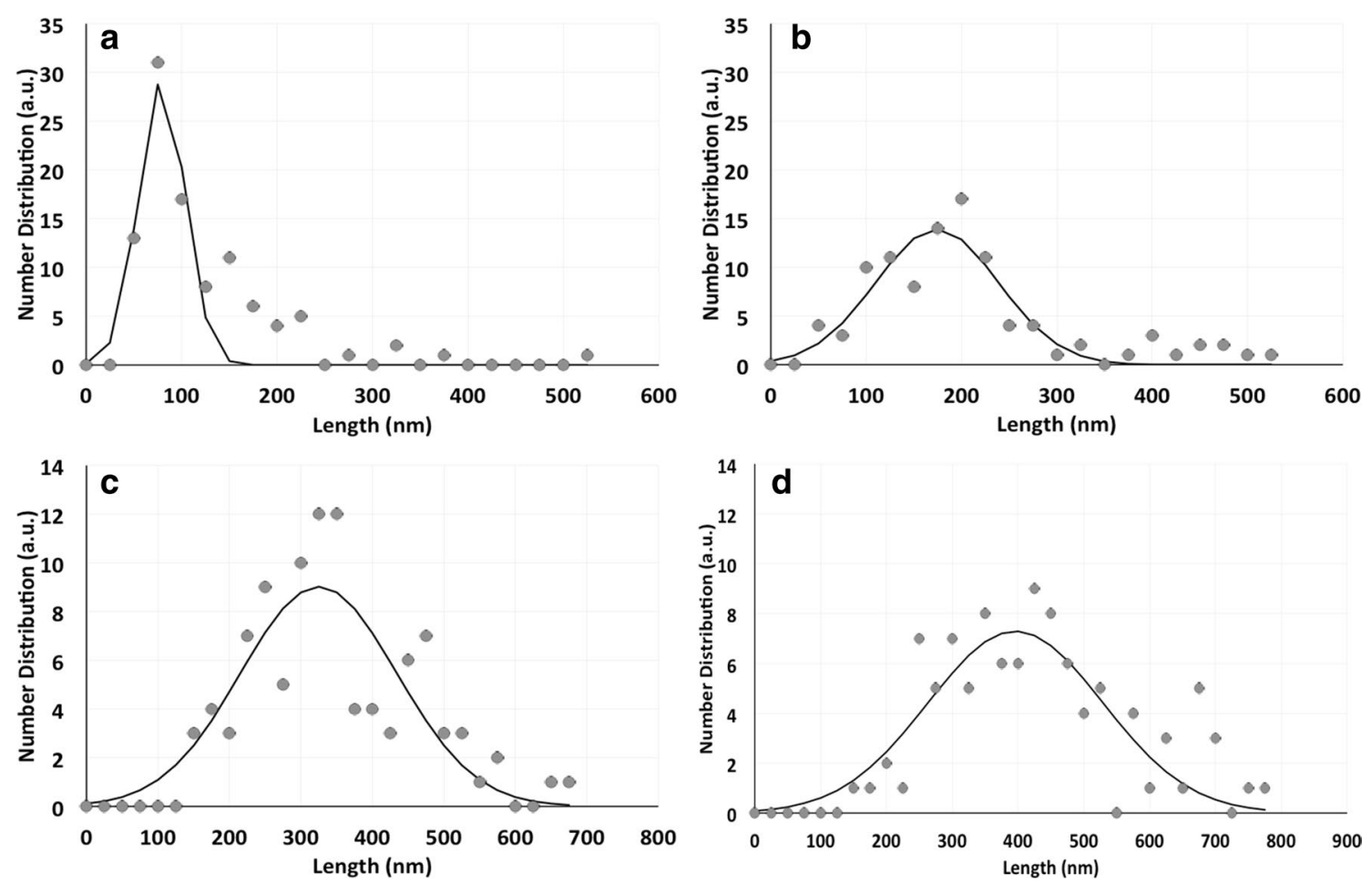

Fig. 5 Length distribution $(\mathrm{nm})$ of TeNRs ${ }_{100}(\mathbf{a})$, and TeNRs ${ }_{500}(\mathbf{b})$ generated by unconditioned $\mathrm{BCP}_{1} \mathrm{~K}_{2} \mathrm{TeO}_{3}$-grown cells, and TeNRs ${ }_{100}(\mathbf{c})$, and TeNRs $_{500}(\mathbf{d})$ isolated from conditioned ones. Length distributions are indicated as grey filled circles, while the Gaussian fit is highlighted as a continuous black curve

recovered from TeNRs produced by unconditioned cells grown in the presence of either 100 or $500 \mu \mathrm{g} / \mathrm{mL}$ of $\mathrm{K}_{2} \mathrm{TeO}_{3}$ were featured by a surface potential of -26 and $-22 \mathrm{mV}$ (Additional file 1: Figure S4a, b), while those obtained from TeNRs $s_{100}$ and TeNRs ${ }_{500}$ generated by conditioned cells had a charge of -29 and $-21 \mathrm{mV}$ (Additional file 1: Figure S4c, d), respectively.

Scanning electron microscopy (SEM) and energy-dispersed X-ray spectroscopy (EDX) analyses

Morphology of TeNRs extracted from BCP1 unconditioned and conditioned cells was evaluated by performing SEM observations (Fig. 6), while the elemental analysis of NRs was performed using energy-dispersed X-ray spectroscopy (EDX) (Fig. 7; Table 1). SEM images showed the presence of not aggregated TeNRs surrounded by a dark grey colored material in background (Fig. 6) similarly to TEM observations. In particular, TeNRs ${ }_{100}$ recovered from unconditioned cells underlined the evidence of some NRs forming circular structures around the edge of the surrounding material, while the $\mathrm{TeNRs}_{500}$ were homogeneously distributed and had a rod-shaped morphology (Fig. 6a, b). Elemental analysis of TeNRs showed the presence of the same chemical elements for different initial concentrations of the precursor $\left(\mathrm{K}_{2} \mathrm{TeO}_{3}\right)$ : carbon, nitrogen, oxygen and tellurium (Fig. 7a, b). However, the relative percentage ratios of these elements differed between the TeNRs ${ }_{100}$ and $\mathrm{TeNRs}_{500}$. The presence of silicon in the elemental analysis was due to the silicon stubs the samples were mounted onto. Excluding the silicon signal, carbon had the highest percentage value in both TeNRs extracted from unconditioned cells, being $39 \%\left(\mathrm{TeNRs}_{100}\right)$ and $49.7 \%\left(\mathrm{TeNRs}_{500}\right)$. EDX quantification data showed a higher amount of nitrogen for $\mathrm{TeNRs}_{500}$ (9\%) as compared to TeNRs $\mathrm{T}_{100}$ (5\%), while oxygen percentage values were comparable for unconditioned TeNRs, yielding $4 \%\left(\mathrm{TeNRs}_{500}\right)$ and $3 \%\left(\mathrm{TeNRs}_{100}\right)$. Similarly, tellurium amounts were comparable between $\mathrm{TeNRs}_{100}(4 \%)$ and $\mathrm{TeNRs}_{500}$ (3\%). Moreover, low content of sulfur $(0.3 \%)$ was detected only in the case of TeNRs $s_{500}$ (Table 1). SEM observations of TeNRs produced by conditioned cells revealed morphologies analogous to those seen in unconditioned cells, with the presence of circular organized NRs in the case of TeNRs ${ }_{100}$ and the typical rod-morphology for TeNRs 500 (Fig. 6c, d). Chemical composition detected by EDX analyses of these nanostructures recovered from conditioned cells indicated the presence of carbon, nitrogen and tellurium (Fig. 7c, d). Carbon showed the highest relative percentage value, being $42 \%\left(\mathrm{TeNRs}_{100}\right)$ and $34 \%\left(\mathrm{TeNRs}_{500}\right)$, while nitrogen 

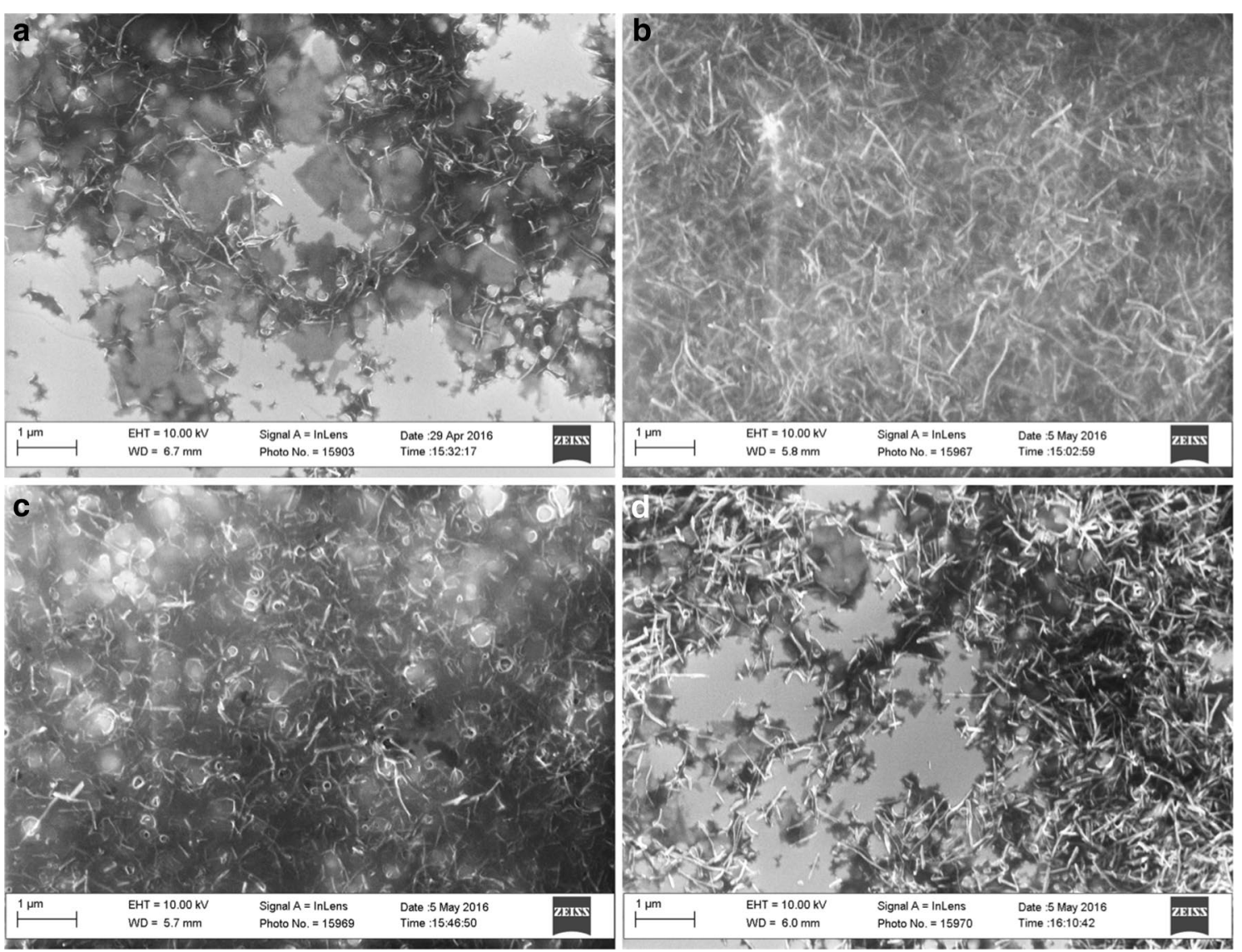

Fig. 6 Scanning electron microscopy (SEM) micrographs of TeNRs ${ }_{100}(\mathbf{a})$, and TeNRs ${ }_{500}$ (b) produced by unconditioned $\mathrm{BCP} \mathrm{K}_{2} \mathrm{TeO}_{3}$-grown cells, and TeNRs $_{100}(\mathbf{c})$, and TeNRs ${ }_{500}(\mathbf{d})$ extracted from those conditioned

amounts were higher in $\mathrm{TeNRs}_{100}(7 \%)$ than $\mathrm{TeNRs}_{500}$ (3\%). Moreover, tellurium percentages underlined a relative value of 6 and $3 \%$ in TeNRs 500 and TeNRs respectively. Finally, only in the case of TeNRs $s_{500}$, EDX data showed the absence of the oxygen signal, which was detected in low content (3\%) in TeNRs ${ }_{100}$ (Table 1).

\section{Discussion}

Although Te is a rare natural element in the Earth crust (0.027 ppm) [12], the widespread use of Te-containing compounds in electronics, optics, production of batteries, petroleum refining and mining [12, 38-40] has led to an increase in its presence in the environment as soluble and toxic oxyanion $\mathrm{TeO}_{3}{ }^{2-}$, causing serious threats to the ecosystem and human health [28]. Interestingly, a large number of Gram-negative [10-13] and Grampositive bacteria [16-18] were reported to be tolerant and/or resistant towards tellurite. A common strategy used by microorganisms to overcome the toxicity of $\mathrm{TeO}_{3}{ }^{2-}$, relies on the reduction of this oxyanion to its less available/toxic elemental form $\left(\mathrm{Te}^{0}\right)$, producing either intracellular metalloid deposits or nanostructures [12]. In this present study, we have evaluated the capacity of an aerobic Gram-positive Rhodococcus strain, Rh. aetherivorans $\mathrm{BCP} 1$, to grow in the presence of high amounts of tellurite (supplied as $\mathrm{K}_{2} \mathrm{TeO}_{3}$ ). The results show that under this extreme growth condition, $\mathrm{BCP} 1$ cells are able not only to grow significantly but they also reduce $\mathrm{TeO}_{3}{ }^{2-}$ generating intracellular Te-nanostructures, which were isolated and characterized. This result is of some importance since in the past it was reported that oxygen greatly enhances the $\mathrm{TeO}_{3}{ }^{2-}$ toxicity to bacterial cells, i.e. from $\mathrm{MIC}^{\mathrm{Te}}$ of 250 to $2 \mu \mathrm{g} / \mathrm{mL}$ under anaerobic and aerobic growth, respectively [41]. Conversely, the tolerance of aerobically grown BCP1 strain towards $\mathrm{TeO}_{3}{ }^{2-}$ oxyanions was very high, with a $\mathrm{MIC}^{\mathrm{Te}}$ value of $2800 \mu \mathrm{g} /$ $\mathrm{mL}(11.2 \mathrm{mM})$. A comparison between BCP1 strain and Gram-positive bacteria described in literature for their ability to grow aerobically in the presence of $\mathrm{K}_{2} \mathrm{TeO}_{3}$ underlines the high tolerance of Rhodococcus aetherivorans BCP1 strain to this oxyanion. Specifically, bacterial strains such as Lysinibacillus sp. ZYM-1, Bacillus sp. BZ, 

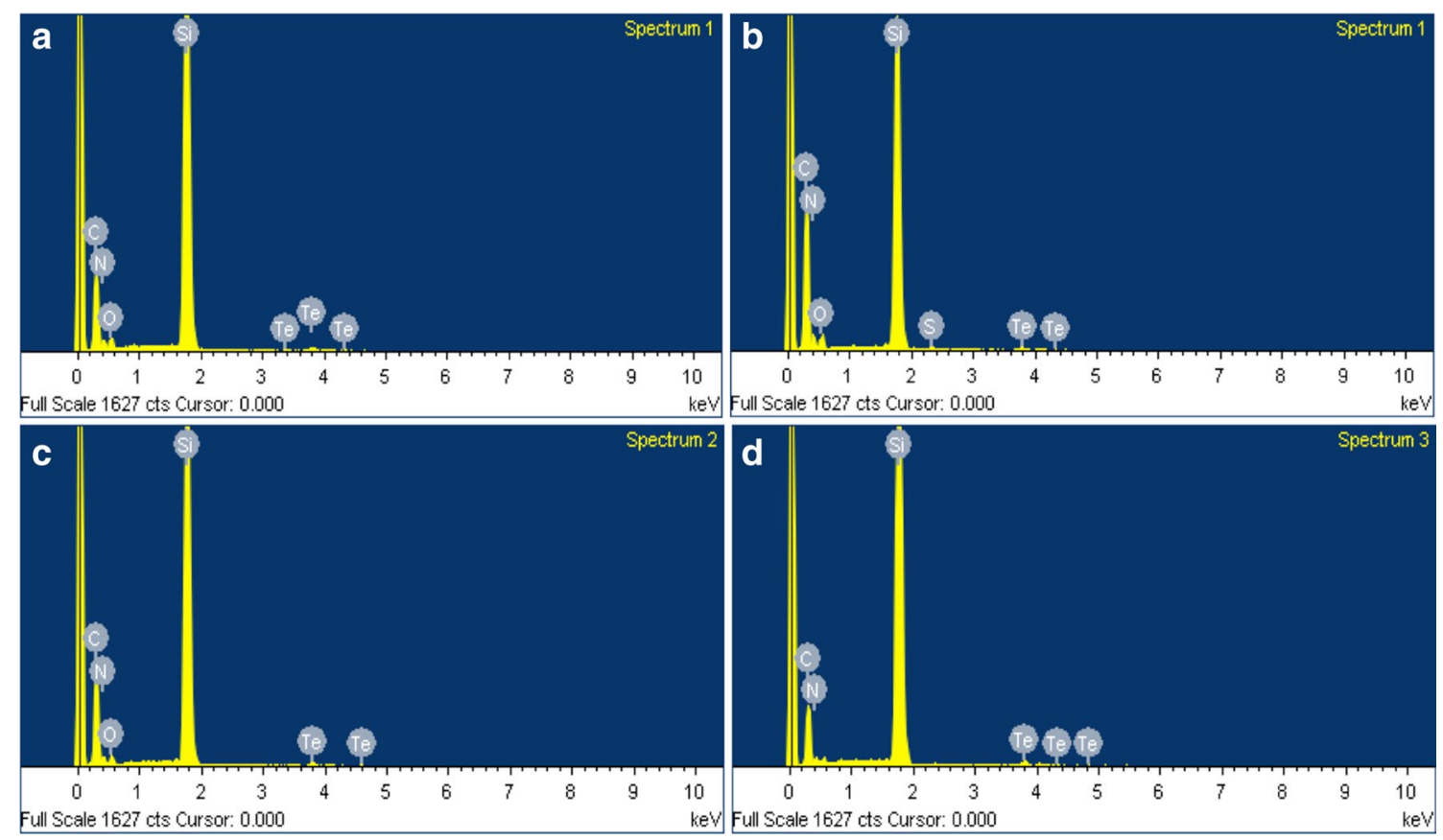

Fig. 7 Energy-dispersed X-ray spectroscopy (EDX) spectra of TeNRs ${ }_{100}(\mathbf{a})$, and TeNRs $\mathrm{T}_{500}(\mathbf{b})$ unconditioned BCP1 grown cells, and TeNRs ${ }_{100}(\mathbf{c})$, and TeNRs $_{500}(\mathbf{d})$ extracted from those conditioned ones grown in the presence of $\mathrm{K}_{2} \mathrm{TeO}_{3}$

Table 1 Elemental quantification (as weight relative percentage) of unconditioned and conditioned TeNRs and TeNRs ${ }_{500}$

\begin{tabular}{|c|c|c|c|c|}
\hline \multirow[t]{3}{*}{ Element } & \multicolumn{2}{|c|}{ Unconditioned } & \multicolumn{2}{|c|}{ Conditioned } \\
\hline & TeNRs $_{100}$ & TeNRs $_{500}$ & TeNRs $_{100}$ & TeNRs $_{500}$ \\
\hline & $\begin{array}{l}\text { Weight } \\
\text { (Rel. \%) }\end{array}$ & $\begin{array}{l}\text { Weight } \\
\text { (Rel. \%) }\end{array}$ & $\begin{array}{l}\text { Weight } \\
\text { (Rel.\%) }\end{array}$ & $\begin{array}{l}\text { Weight } \\
\text { (Rel.\%) }\end{array}$ \\
\hline Silicon (Si) & 49 & 34 & 45 & 57 \\
\hline Tellurium (Te) & 4 & 3 & 3 & 6 \\
\hline Carbon (C) & 39 & 49.7 & 42 & 34 \\
\hline Oxygen (O) & 3 & 4 & 3 & N.D. \\
\hline Nitrogen (N) & 5 & 9 & 7 & 3 \\
\hline Sulfur (S) & N.D. & 0.3 & N.D. & N.D. \\
\hline
\end{tabular}

Elemental quantification is expressed as Weight Relative Percentage of the element detected in the TeNRs samples

Element not detected are indicated as N.D

Corynebacterium diphtheriae, Bacillus sp. STG-83, Paenibacillus TeW, and Salinicoccus sp. QW6 were described for their ability to tolerate $\mathrm{TeO}_{3}{ }^{2-}$, with an $\mathrm{MIC}^{\mathrm{Te}}$ values ranging from 0.8 to $12 \mathrm{mM}$ [18-23] (Table 2).

Among the species of Actinomycetales order, BCP1 strain tolerance is therefore ten times higher than the $\mathrm{MIC}^{\mathrm{Te}}(1 \mathrm{mM})$ of Corynebacterium diphtheriae [18]. Conversely, the $\mathrm{MIC}^{\mathrm{Te}}$ of $\mathrm{BCP} 1$ strain was comparable to that obtained with Salinicoccus sp. QW6, which is equal
Table 2 Comparison of the minimal inhibitory concentration of tellurite $\left(\mathrm{MIC}^{\mathrm{Te}}\right.$ ) supplied as potassium tellurite $\left(\mathrm{K}_{2} \mathrm{TeO}_{3}\right)$ to rich medium among Gram-positive bacteria grown under aerobic conditions

\begin{tabular}{lll}
\hline Strain & MIC $^{\text {Te }}$ (mM) & References \\
\hline Salinicoccus sp. QW6 & 12 & Amoozegar et al. [23] \\
Rhodococcus aetherivorans BCP1 & 11.2 & This study \\
Lysinibacillus sp. ZYM-1 & 2 & Zhao et al. [19] \\
Bacillus sp. STG-83 & 1.25 & Soudi et al. [21] \\
Corynebacterium diphtheriae & 1 & Tucker et al. [18] \\
Paenibacillus TeW & 1 & Chien et al. [22] \\
Bacillus sp. BZ & 0.8 & Zare et al. [20] \\
\hline
\end{tabular}

to $12 \mathrm{mM}$ [23]. In this respect, the high tolerance of the BCP1 cells towards $\mathrm{TeO}_{3}{ }^{2-}$ oxyanions under aerobic conditions suggests that this microorganism might play a key role in the in situ and/or ex situ decontamination procedures of $\mathrm{TeO}_{3}{ }^{2-}$ polluted environments.

In order to evaluate differences in the growth, in the reduction of $\mathrm{TeO}_{3}{ }^{2-}$, as well as in the production of TeNRs by BCP1 strain, unconditioned and conditioned cells were exposed to either 100 or $500 \mu \mathrm{g} / \mathrm{mL}$ (0.4 or $2 \mathrm{mM}) \mathrm{K}_{2} \mathrm{TeO}_{3}$. The complete reduction of $100 \mu \mathrm{g} / \mathrm{mL}$ $\mathrm{TeO}_{3}{ }^{2-}$ to elemental $\mathrm{Te}^{0}$ within $36 \mathrm{~h}$ was observed for conditioned $\mathrm{BCP} 1$ grown cells as compared to the unconditioned ones (48 h). Similarly, Amoozegar et al. [23] 
observed that Salinicoccus sp. QW6 was able to completely reduce $0.5 \mathrm{mM}(125 \mu \mathrm{g} / \mathrm{mL})$ of $\mathrm{K}_{2} \mathrm{TeO}_{3}$ within $72 \mathrm{~h}$ under aerobic conditions. There was no increased removal detected by the QW6 strain at greater concentrations, even after $144 \mathrm{~h}$ of incubation. Additionally, an incomplete reduction of $\mathrm{TeO}_{3}{ }^{2-}$ was described by Zare et al. [20] in the case of Bacillus sp. BZ incubated in Nutrient Broth medium supplemented with 50 or $100 \mu \mathrm{g} /$ $\mathrm{mL}(0.2$ or $0.4 \mathrm{mM})$ of $\mathrm{K}_{2} \mathrm{TeO}_{3}$ within 50 h of exposure. By contrast, when the $\mathrm{BCP} 1$ strain was incubated in the presence of $500 \mu \mathrm{g} / \mathrm{mL}$ of $\mathrm{K}_{2} \mathrm{TeO}_{3}$, the reduction of the initial concentration of $\mathrm{TeO}_{3}{ }^{2-}$ oxyanions resulted to be higher in the case of BCP1 conditioned grown cells $(348 \mu \mathrm{g})$ rather than the unconditioned ones $(218 \mu \mathrm{g})$, within 5 culturing days. Nevertheless, an incomplete reduction of the $\mathrm{TeO}_{3}{ }^{2-}$ added $(500 \mu \mathrm{g} / \mathrm{mL})$ was observed. Although cellular thiols (RSH) and glutathione (GSH) molecules are likely to reduce $\mathrm{TeO}_{3}{ }^{2-}$ oxyanions [5] with a consequence of a strong cytoplasmic redox unbalance of the glutathione/glutaredoxin and thioredoxin pool [42, 43], it is noteworthy that glutathione molecules are not commonly present in Actinobacteria, except in the case of horizontal gene transfer [44]. In Actinomycetes strains, analogous functions to glutathione (GSH) molecules are performed by mycothiols (MSH; also designated AcCysGlcN-Ins), which are the major species of thiols present [45]. Similarly to GSHs, MSHs are able to reduce metals and toxic compounds thanks to the presence of thiol groups in cysteine moieties [45], which provide three possible metal ligands $\left(-\mathrm{S}^{-},-\mathrm{NH}_{2},-\mathrm{COO}^{-}\right)$. The result of these oxidation-reduction reactions is the production of reactive oxygen species (ROS) e.g. hydrogen peroxide, which cause cellular death [46]. On the other hand, both GSH and MSH molecules are less prone to the oxidation when amino and carboxylic groups are blocked by $\gamma$-glutamyl and glycine residues or acetyl and GlcN-Ins, respectively $[47,48]$. In this respect, the capacity of $\mathrm{BCP} 1$ cells to grow aerobically and tolerate high concentrations of tellurite might be due to the greater redox stability of MSHs as compared to GSHs [49], under oxidative stress conditions generated by the simultaneous presence of oxygen and $\mathrm{TeO}_{3}{ }^{2-}$. Moreover, catalase, which is a key enzyme that overcomes cellular oxidative stress, is able to reduce tellurite to its elemental form $\left(\mathrm{Te}^{0}\right)$, conferring the resistance to aerobic microorganisms towards this oxyanion [50]. However, the mechanism of tellurite resistance for Gram-positive bacteria belonging to the order of Actinomycetales is scarcely studied. Nevertheless, it is noteworthy to mention the study of Terai and coworkers [51], in which a cell free extract of Mycobacterium avium was able to reduce tellurite with a non-specific interaction. Furthermore, among tellurite-resistant Gram-positive bacteria, Bacillus sp. STG-83 was characterized for its ability to reduce these oxyanions using a cytoplasmic tellurite reductase [52], while the product of the genes cysK (cysteine synthase), cobA (uroporphyrinogen-III C-methyltransferase), iscS (cysteine desulfurase) of Geobacillus stearothermophilus $\mathrm{V}$ conferred resistance to the E. coli $\mathrm{K}-12$ strain towards potassium tellurite [53-55].

The production of intracellular Te-deposits as a consequence of $\mathrm{TeO}_{3}{ }^{2-}$ reduction was earlier described in Gram-positive bacteria such as Paenibacillus TeW and Salinicoccus sp. QW6 [22, 23], while Baesman and coworkers reported on the presence of Te-nanostructures in the form of clusters/rosettes accumulated on the outer cell surfaces of $B$. beveridgei and B. selenitireducens [16, 17]. In detail, the Te-nanostructures produced by Bacillus strains clustered together after their synthesis, forming larger and thicker shard-like structures, which were able to adhere each other and to collapse into bigger rosettes $[16,17]$. Conversely, our present TEM images of BCP1 unconditioned cells grown in the presence of either 100 or $500 \mu \mathrm{g} / \mathrm{mL}$ of $\mathrm{K}_{2} \mathrm{TeO}_{3}$ revealed the presence of intracellular stable Te-nanorods (TeNRs), similar to those described by Zare and colleagues in Bacillus sp. BZ [20]. Moreover, TeNRs isolated from unconditioned or conditioned $\mathrm{BCP} 1$ cells as seen by TEM and SEM analyses, still appeared in the form of individual and not clustered rod-shaped nanostructures (Figs. 4, 6). Isolated TeNRs were embedded into a slightly electron-dense surrounding material, whose organic nature was revealed by signals corresponding to carbon, oxygen, nitrogen and sulfur as detected by EDX spectroscopy. Similar observations were recently obtained by Zonaro and coworkers studying Tenanoparticles (TeNPs) produced by the Gram-negative Ochrobactrum sp. MPV1 strain [26]. The zeta potential measurements highlighted a similar negative potential of either studied TeNRs suspensions or the supernatants recovered from Te-nanostructures (Additional file 1: Figures S3, S4), reinforcing the indication of an organic material associated with the $\mathrm{BCP} 1 \mathrm{TeNRs}$, possibly involved in stabilizing these nanostructures, since tellurium does not have a net charge in its elemental state $\left(\mathrm{Te}^{0}\right)$. Our conclusion is also in line with the study by Wang et al. [56], who ascribed the strong negative surface potential of chemically synthetized Te-nanowires to carboxylic groups of L-cysteine ligands in solution. Moreover, DLS analyses of all studied TeNRs samples showed size distributions that were virtually indistinguishable for TeNRs extracted from BCP1 unconditioned and conditioned grown cells. The only factor that appeared to have an effect on the measured sizes was the initial concentration of $\mathrm{TeO}_{3}{ }^{2-}(100$ or $500 \mu \mathrm{g} / \mathrm{mL}$ ). Additionally, the size distributions of the analyzed supernatants recovered after removing TeNRs showed peaks slightly shifted towards smaller sizes. These results suggest that the size distributions obtained by 
DLS for all TeNRs suspensions do not depend only on the presence of the nanorods in the samples. Nanostructures are known to have a high surface energy and may be thermodynamically unstable in suspension [57]. The stability of nano-suspensions is increased if there is an electrostatic repulsion between the particles due to the presence of charges on the surface or if the surface is coated with molecules that prevent the particles to come into close contact with each other and collapse into aggregates [58, 59]. The latter form of stabilization, so called steric stabilization, is widely used in chemical synthesis of nanoparticles and nanorods [60]. In the case of TeNRs produced by the BCP1 strain, both electrostatic and steric stabilization seem to play a role. The organic matter surrounding TeNRs is charged as confirmed by zeta potential measurements. It is important to mention that the presence of the organic surrounding material in solution is essential to the stability of TeNRs. Our attempts to remove it from the nanorods suspensions by several rounds of centrifugation resulted in an irreversible aggregation of the TeNRs. This result combined with the DLS and Zeta potential data suggest that ( 1 the organic surrounding material is not covalently attached to the surface of TeNRs, and (2) it is adsorbed on the surface and also present in solution in equilibrium, playing a crucial role in the colloidal stability of TeNRs. We have not been able to confirm the identy of these organic molecules. However, there is a strong possibility that hydrophobic molecules, either lipids or a secreted biosurfactant may be the major constituents of the mixture. There are at least two arguments in favor of this hypothesis. First, due its amphiphilic properties lipids are known to form nanosized aggregates when suspended in aqueous solution. Such nanostructures were observed by DLS even after the nanorods were removed from solution. Second, chemical synthesis of nanorods typically requires the presence of a surfactant at high concentrations to drive their synthesis to one direction [61]. In this regard, Rhodococcus species are known to produce biosurfactant molecules such as trehalose mycolates and glycolipids under physiological and nitrogen limiting growth conditions [62, 63], respectively. Therefore, it is reasonable to suggest that the nanorod formation may be mediated by the biosurfactant co-produced by the BCP1 strain.

Due to the presence of TeNRs embedded in an undefined organic material, the actual length of the nanorods was established using ImageJ software based on TEM images. As a result, an incremented length of TeNRs was observed as function of the tellurite concentration (100 or $500 \mu \mathrm{g} / \mathrm{mL}$ of $\mathrm{K}_{2} \mathrm{TeO}_{3}$ ), as well as the condition of growth as unconditioned or conditioned cells. In this regard, the dependence of TeNRs length on the initial concentration of the available precursor $\left(\mathrm{TeO}_{3}{ }^{2-}\right)$ was reported for the production of chemically synthesized nanostructures [64], while the variation of nanorods size as function of the growth conditions (unconditioned or conditioned cells) may be explained by the LaMer mechanism of nanomaterials formation. According to this mechanism, when the reduction of the precursor to its elemental form occurs, a high concentration of monomers in solution is produced, leading to the formation of nucleation seeds that subsequently grow as nanostructures [65]. Most likely, the reduction of the precursor $\left(\mathrm{TeO}_{3}{ }^{2-}\right)$ by unconditioned $\mathrm{BCP} 1$ cells led to the production of a high concentration of monomers $\left(\mathrm{Te}^{0}\right)$ inside the cells, followed by the formation of Te-seeds of nucleation, which finally grew as TeNRs. As a consequence of the unconditioned growth, some Te-seeds of nucleation were still present inside the cells re-inoculated to perform the conditioned growth, which might be used by conditioned cells to produce longer TeNRs.

Several Rhodococcus strains were previously described for their ability to generate metal nanostructures i.e. gold (AuNPs) [66], silver (AgNPs) [67], and zinc oxide (ZnONPs) [68] nanoparticles; however, these rhodococci were scarcely investigated as cell factories for the production of metalloid nanostructures. To the best of our knowledge, this is the first report on the synthesis of rod-shaped nanostructures made of elemental tellurium (TeNRs) by a bacterial strain belonging to the Rhodococcus genus.

\section{Conclusions}

The capacity of the BCP1 strain belonging to Rhodococcus genus to grow aerobically in the presence of high amounts of the toxic oxyanion tellurite and to reduce it into elemental tellurium $\left(\mathrm{Te}^{0}\right)$ was assessed. In particular, conditioned $\mathrm{BCP} 1$ cells were able to reduce a greater amount of $\mathrm{TeO}_{3}{ }^{2-}$ oxyanions at a faster rate as compared to unconditioned cells. The estimated MIC value $(2800 \mu \mathrm{g} / \mathrm{mL}$ or $11.2 \mathrm{mM})$ of $\mathrm{TeO}_{3}{ }^{2-}$ for aerobic growth of BCP1 strain underlined its feature to tolerate high concentration of this toxic oxyanion, as compared to other Gram-positive bacteria previously described as telluritetolerant and/or resistant microorganisms. Additionally, the BCP1 strain was able to produce intracellular rodshaped nanostructures, which did not aggregate. These TeNRs were embedded in an organic surrounding material, showing an increasing length as function of tellurite concentration (100 or $500 \mu \mathrm{g} / \mathrm{mL}$ of $\mathrm{K}_{2} \mathrm{TeO}_{3}$ ) and the growth condition such as unconditioned or conditioned cells.

Since tellurium is a versatile narrow band-gap p-type semiconductor [69], this element exhibits unique properties such as photoconductivity, high piezoelectricity, thermoelectricity [70], non-linear optical response [71]. In this respect, TeNRs have found applications as 
optoelectronic, thermoelectric, piezoelectric devices, as well as gas sensors and infrared detectors [72-76]. Moreover, TeNRs have been investigated for their antibacterial, antioxidant and anticancer properties [77]. Although further investigations are required in order to evaluate the potential use of TeNRs synthetized by Rhodococcus aetherivorans $\mathrm{BCP} 1$, the present study demonstrated that aerobically grown BCP1 strain can be utilized as a cell factory for metalloid nanostructure production.

\section{Additional file}

Additional file 1. Additional information.

\begin{abstract}
Authors' contributions
$A P$ and EP equally contributed to the scientific development of this study, namely: (1) performing of the experiments, (2) data interpretation, (3) major contribution to the writing of the manuscript. MA, instructor at the Chemistry Department of the University of Calgary, participated in the characterization analyses of TeNRs along with the interpretation of the data and editing of the chemical-physical part of the manuscript. MC, research associate in the Unit of General and Applied Microbiology at the Department of Pharmacy and Biotechnology of the University of Bologna, participated in the revision of the manuscript giving important suggestions for a better interpretation of the biological results. DZ, full professor and coordinator of the Unit of General and Applied Microbiology at the Department of Pharmacy and Biotechnology of the University of Bologna, allowed the use of the Rhodococcus aetherivorans $\mathrm{BCP} 1$ strain and intellectually contributed to the interpretation and development of this study. RJT, full professor and coordinator of the Microbial Biochemistry Laboratory at the Department of Biological Sciences of the Calgary University, had a major intellectual and financial contribution during the development of this study, managing and directing the research as well as editing and revising the manuscript. All authors read and approved the final manuscript.
\end{abstract}

\section{Author details \\ ${ }^{1}$ Microbial Biochemistry Laboratory, Department of Biological Sciences, University of Calgary, 2500 University Dr. NW, Calgary, AB T2N 1N4, Canada. ${ }^{2}$ Department of Chemistry, University of Calgary, 2500 University Dr. NW, Cal- gary, AB T2N 1N4, Canada. ${ }^{3}$ Department of Pharmacy and Biotechnology, Unit of General and Applied Microbiology, Via Irnerio 42, Bologna 40126, Italy.}

\section{Acknowledgements}

Natural Science and Engineering Research Council of Canada (NSERC) is gratefully acknowledged for the support of this study. We also acknowledge the Nanoscience Program at the University of Calgary for providing access to SEM, EDX, DLS, and Zeta-potential measurements and Microscopy Imaging Facility (MIF) at the University of Calgary for providing access to TEM.

\section{Competing interests}

The authors declare that they have no competing interests.

\section{Availability of data and materials}

All data generated or analyzed during this study are included in this manuscript.

\section{Funding}

This study was funded by Natural Science and Engineering Research Council of Canada (NSERC).

Received: 22 August 2016 Accepted: 24 November 2016

Published online: 15 December 2016

\section{References}

1. Dittmer DC. Tellurium. Chem Eng News. 2003;81:128.

2. Cairnes DD. Canadian-containing ores. J Can Min Inst. 1911;14:185-202.

3. Haynes WM. Section 4: properties of the elements and inorganic compounds. In CRC Handbook of chemistry and physics. 95th ed. Routledge: CRC Press/Taylor and Francis. 2014; p.115-20.

4. Cooper WC. Tellurium. New York: Van Nostrand Renhod Co; 1971.

5. Turner RJ. Tellurite toxicity and resistance in Gram-negative bacteria. Rec Res Dev Microbiol. 2001;5:69-77.

6. Taylor DE. Bacterial tellurite resistance. Trends Microbiol. 1999;7:111-5.

7. Nies D. Microbial heavy-metal resistance. Appl Microbiol Biotechnol. 1999;51:730-50.

8. Harrison JJ, Ceri H, Stremick CA, Turner RJ. Biofilm susceptibility to metal toxicity. Environ Microbiol. 2004;6:1220-7.

9. Jobling MG, Ritchie DA. Genetic and physical analysis of plasmid genes expressing inducible resistance to tellurite in Escherichia coli. Mol Gen Genet. 1987;208:288-93.

10. Borghese R, Brucale M, Fortunato G, Lanzi M, Mezzi A, Valle F, Cavallini $M$, Zannoni D. Extracellular Production of tellurium nanoparticles by the photosynthetic Bacterium Rhodobacter capsulatus. J Hazard Mater. 2016;309:202-9.

11. Klonowska A, Heulin T, Vermeglio A. Selenite and tellurite reduction by Shewanella oneidensis. Appl Environ Microbiol. 2005;71:5607-9.

12. Di Tommaso G, Fedi S, Carnevali M, Manegatti M, Taddei C, Zannoni D. The membrane-bound respiratory chain of Pseudomonas pseudoalcaligenes KF707 cells grown in the presence or absence of potassium tellurite. Microbiology. 2002;148:1699-708.

13. Turner RJ, Weiner JH, Taylor DE. Tellurite-mediated thiol oxidation in Escherichia coli. Microbiology. 1999;145:2549-57.

14. Yurkov V, Beatty JT. Aerobic anoxygenic phototrophic bacteria. Microbiol Mol Bio Rev. 1998;62(3):695-724.

15. Yurkov VV, Jappè J, Vermeglio A. Tellurite resistance and reduction by obligately aerobic photosynthetic bacteria. Appl Environ Microbiol. 1996;62:4195-8.

16. Baesman SM, Stolz JF, Kulp TR, Oremland RS. Enrichment and isolation of Bacillus beveridgei sp. nov., a facultative anaerobic haloalkaliphile from Mono Lake, California, that respires oxyanions of tellurium, selenium, and arsenic. Extremophiles. 2009;13:695-705.

17. Baesman SM, Bullen TD, Dewald J, Zhang DH, Curran S, Islam FS, et al. Formation of tellurium nanocrystals during anaerobic growth of bacteria that use Te oxyanions as respiratory electron acceptors. Appl Environ Microbiol. 2007;73:2135-43.

18. Tucker FL, Thomas JW, Appleman MD, Donohue J. Complete reduction of tellurite to pure tellurium metal by microorganisms. J Bacteriol. 1962;83:1313-4.

19. Zhao Y, Dong Y, Zhang Y, Che L, Pan H, Zhou H. Draft genome sequence of a selenite- and tellurite-reducing marine bacterium, Lysinibacillus sp. strain ZYM-1. Genome Announc. 2016;4:1.

20. Zare B, Faramarzi MA, Sepehrizadeh Z, Shakibaie M, Rezaie S, Shahverdi AR. Biosynthesis and recovery of rod-shaped tellurium nanoparticles and their bactericidal activities. Mat Res Bull. 2012;47:3719-25.

21. Soudi MR. Ghazvini PTM., Khajeh K., Gharavi S. Bioprocessing of selenooxyanions and tellurite in a novel Bacillus sp. strain STG-83: a solution to removal of toxic oxyanions in presence of nitrate. J Hazard Mater. 2009;165:71-7.

22. Chien CC, Han CT. Tellurite restitance and reduction by a Paenibacillus sp. isolated from heavy metal-contaminated sediment. Environ Toxicol Chem. 2009;28:1627-32.

23. Amoozegar MA, Ashengroph M, Malekzadeh F, Razavi MR, Naddaf S, Kabiri M. Isolation and initial characterization of the tellurite reducing moderately halophilic bacterium, Salinicoccus sp. strain QW6. Microbiol Res. 2008;163:456-65.

24. Turner RJ, Borghese R, Zannoni D. Microbial processing of tellurium as a tool in biotechnology. Biotechnol Adv. 2012;30:954-63.

25. Kim DH, Kanaly RA, Hur HG. Biological accumulation of tellurium nanorod structures via reduction of tellurite by Shewanella oneidensis MR-1. Bioresour Technol. 2012;125:127-31. 
26. Zonaro E, Lampis S, Turner RJ, Qazi SJS, Vallini G. Biogenic selenium and tellurium nanoparticles synthetized by environmental microbial isolates efficaciously inhibit bacterial planktonic cultures and biofilms. Front Microbiol. 2015;6:584.

27. Ingale AG, Chaudhari AN. Biogenic synthesis of nanoparticles and potential applications: an ecofriendly approach. J Nanomed Nanotechnol. 2013:4:165.

28. Das S, Dash HR, Chakraborty J. Genetic basis and importance of metal resistant genes in bacteria for bioremediation of contaminated environments with toxic metal pollutants. Appl Microbiol Biotechnol. 2016:100:2967-84.

29. Lampis S, Zonaro E, Bertolini C, Bernardi P, Butler CS, Vallini G. Delayed formation of zero-valent selenium nanoparticles by Bacillus mycoides SelTE01 as a consequence of selenite reduction under aerobic conditions. Microb Cell Fact. 2014;13:35.

30. Martínková L, Uhnáková B, Pátek M, Nesvera J, Kren V. Biodegradation potential of the genus Rhodococcus. Environ Int. 2009;35:162-77.

31. Alvarez HM, Steinbuchel A. Physiology, biochemistry and molecular biology of triacylglycerol accumulation by Rhodococcus. In Biology of Rhodococcus volume 16 of the series Microbiology monographs. Springer: Heidelberg; 2010. p. 263-90.

32. Cappelletti M, Presentato A, Milazzo G, Turner RJ, Fedi S, Frascari D, Zannoni D. Growth of Rhodococcus sp. strain BCP1 on gaseous n-alkanes: new metabolic insights and transcriptional analysis of two soluble di-iron monooxygenase genes. Front Microbiol. 2015;6:393.

33. Frascari D, Pinelli D, Nocentini M, Fedi S, Pii Y, Zannoni D. Chloroform degradation butane-grown cells of Rhodococcus aetherovorans BCP1. Appl Microbiol Biotechnol. 2006;73:421-8.

34. Cappelletti M, Fedi S, Frascari D, Ohtake H, Turner RJ, Zannoni D. Analyses of both the alkB gene transcriptional start site and alkB promoter-inducing properties of Rhodococcus sp. strain BCP1 grown on n-alkanes. Appl Environ Microbiol. 2011;77:1619-27.

35. Orro A, Cappelletti M, D’Ursi P, Milanesi L, Di Canito A, Zampolli J, Collina E, Decorosi F, Viti C, Fedi S, Presentato A, Zannoni D, Di Gennaro P. Genome and phenotype microarray analyses of Rhodococcus sp. BCP1 and Rhodococcus opacus R7: genetic determinants and metabolic abilities with environmental relevance. PLoS ONE. 2015;10(10):e0139467.

36. Cappelletti M, Fedi S, Zampolli J, Di Canito A, D'ursi P, Orro A, Viti C, Milanesi L, Zannoni D, Di Gennaro P. Phenotype microarray analysis may unravel genetic determinants of the stress response by Rhodococcus aetherivorans BCP1 and Rhodococcus opacus R7. Res Microbiol. 2016:1-8.

37. Turner RJ, Weiner JH, Taylor DE. Use of diethyldithiocarbamate for quantitative determination of tellurite uptake by bacteria. Anal Biochem. 1992;204:292-5.

38. Tang Z, Zhang Z, Wang Y, Glotzer SC, Kotov NA. Self-assembly of CdTe nanocrystals into free-floating sheets. Science. 2006;314:274-8.

39. Graf C, Assoud A, Mayeasree O, Kleinke H. Solid state polyselenides and polytellurides: a large variety of $\mathrm{Se}-\mathrm{Se}$ and $\mathrm{Te}-\mathrm{Te}$ interactions. Molecules. 2009;14:15-31.

40. Sen S, Sharma M, Kumar V, Muthe KP, Satyam PV, Bhatta VM, Roy M, Gaur NK, Gupta SK, Yakhmi JV. Chlorine gas sensors using one-dimensional tellurium nanostructures. Talanta. 2009;77:1567-72.

41. Borghese R, Borsetti F, Foladori P, Ziglio G, Zannoni D. Effects of the Metalloid Oxyanion Tellurite $\left(\mathrm{TeO}_{3}{ }^{2-}\right)$ on growth characteristics of the phototrophic Bacterium Rhodobacter capsulatus. Appl Environ Microbiol. 2004:70:6595-602.

42. Carmel-Harel O, Storz G. Roles of the glutathione- and thioredoxin dependent reduction systems in the Escherichia coli and Saccharomyces cerevisiae responses to oxidative stress. Ann Rev Microbiol. 2000;54:439-61.

43. Aslund F, Beckwith J. Bridge over troubled waters: sensing stress by disulfide bond formation. Cell. 1999;96:751-3.

44. Newton GL, Buchmeier N, Fahey RC. Biosynthesis and functions of mycothiol, the unique protective thiol of Actinobacteria. Microbiol Mol Biol Rev. 2008;72:471-94.

45. Newton GL, Arnold K, Price MS, Sherrill C, delCardayre SB, Aharonowitz Y, Cohen G, Davies J, Fahey RC, Davis C. Distribution of thiols in microorganisms: mycothiol is a major thiol in most actinomycetes. J Bacteriol. 1996;178:1990-5.
46. Held KD, Biaglow JE. Mechanisms for the oxygen radical mediated toxicity of various thiol-containing compounds in cultured mammalian cells. Radiat Res. 1994;139:15-23.

47. Sundquist AR, Fahey RC. The function of gamma-glutamylcysteine and bis-gamma-glutamylcystine reductase in Halobacterium halobium. J Biol Chem. 1989;264:719-25.

48. Newton GL, Bewley CA, Dwyer TJ, Horn R, Aharonowitz Y, Cohen G, Davies J, Faulkner DJ, Fahey RC. The structure of U17 isolated from Streptomyces clavuligerus and its properties as an antioxidant thiol. Eur J Biochem. 1995;230:821-5.

49. Newton GL, Ta P, Fahey RC. A mycothiol synthase mutant of Mycobacterium smegmatis produces novel thiols and has an altered thiol redox status. J Bacteriol. 2005;187:7309-16.

50. Calderón IL, Arenas FA, Pérez JM, Fuentes DE, Araya MA, Saavedra CP, Tantaleán JC, Pichuantes SE, Youderian PA, Vásquez CC. Catalases are NAD(P) H-dependent tellurite reductases. PLoS ONE. 2006;1:1-8.

51. Terai T, Kamahora T, Yamamura Y. Tellurite reductase from Mycobacterium avium. J Bacteriol. 1958;75:535-9.

52. Etezad SM, Khajeh K, Soudi M, Ghazvini PTM, Dabirmanesh B. Evidence on the presence of two distinct enzymes responsible for the reduction of selenate and tellurite in Bacillus sp. STG-83. Enzyme Microbial Technol. 2009:45:1-6.

53. Vásquez CC, Saavedra CP, Loyola CA, Araya MA, Pichuantes S. The product of the cysK gene of Bacillus stearothermophilus $V$ mediates potassium tellurite resistance in Escherichia coli. Curr Microbiol. 2001;43:418-23.

54. Araya MA, Tantaleán JC, Pérez JM, Fuentes DE, Calderón IL, Saavedra CP, Burra R, Chasteen TG, Vásquez CC. Cloning, purification and characterization of Geobacillus stearothermophilus V uroporphyrinogen-III C-methyltransferase: evaluation of its role in resistance to potassium tellurite in Escherichia coli. Res Microbiol. 2009;160(125):133.

55. Tantaleán JC, Araya MA, Saavedra CP, Fuentes DE, Pérez JM, Calderón IL, Youderian P, Vásquez CC. The Geobacillus stearothermophilus V iscS gene, encoding cysteine desulfurase, confers resistance to potassium tellurite in Escherichia coli K-12. J Bacteriol. 2003;185(9):5737-831.

56. Wang Y, Tang Z, Podsiadlo P, Elkasabi Y, Lahann J, Kotov NA. Mirrorlike photoconductive layer-by-layer thin films of te nanowires: the fusion of semiconductor, metal, and insulator properties. Adv Mater. 2006;18:518-22.

57. Claus $\mathrm{P}, \mathrm{Hofmeister} \mathrm{H}$. electron microscopy and catalytic study of silver catalysts: structure sensitivity of the hydrogenation of crotonaldehyde. J Phys Chem B. 1999;103:2766-75.

58. Kraynov A, Müller TE. Chapter 12: concepts for the stabilization of metal nanoparticles in ionic liquids. In: Handy S, (editors). Applications of ionic liquids in science and technology. INTECH Open Access Publisher; 2011. p. $235-60$.

59. Aiken JD, Finke RG. A review of modern transition-metal nanoclusters: their synthesis, characterization, and applications in catalysis. J Mol Catal A Chem. 1999:145(1):1-44.

60. Starkey Ott L, Finke RG. Transition-metal nanocluster stabilization for catalysis: a critical review of ranking methods and putative stabilizers. Coord Chem Rev. 2007;251:1075-100.

61. Rao CNR, Deepak FL, Gundiah G, Govindaraj A. Inorganic nanowires Progr Solid State Chem. 2003;31:5-147.

62. Rapp P, Bock H, Wray $V$, Wagner F. Formation, isolation and characterization of trehalose dimycolates from Rhodococcus erythropolis grown on n-alkanes. J Gen Microbiol. 1979;115:491-503.

63. Kim JS, Powalla M, Lang S, Wagner F, Lunsdorf H, Wray V. Microbial glycolipid production under nitrogen limitation and resting cell condition. J Bacteriol. 1990;13:257-66.

64. Gautam UK, Rao CNR. Controlled synthesis of crystalline tellurium nanorods, nanowires, nanobelts and related structures by a self-seeding solution process. J Mater Chem. 2004;14:2530-5.

65. Thanh NTK, Maclean N, Mahiddine S. Mechanisms of nucleation and growth of nanoparticles in solution. Chem Rev. 2014;114:7610-30.

66. Ahmad A, Senapati S, Khan MI, Kumar R, Ramani R, Srinivas V, Sastry M Intracellular synthesis of gold nanoparticles by a novel alkalotolerant actinomycete Rhodococcus species. Nanotechnology. 2003;14:824-8.

67. Otari SV, Patil RM, Nadaf NH, Ghosh SJ, Pawar SH. Green biosynthesis of silver nanoparticles from an actinobacteria Rhodococcus sp. Mater Lett. 2012:72:92-4 
68. Kundu D, Hazra C, Chatterjee A, Chaudhari A, Mishra S. Extracellular biosynthesis of zinc oxide nanoparticles using Rhodococcus pyridinivorans NT2: multifunctional textile finishing, biosafety evaluation and in vitro drug delivery in colon carcinoma. J Photochem Photobiol B. 2014;140:194-204.

69. Zhao A, Zhang L, Yang Y, Ye C. Ordered tellurium nanowire arrays and their optical properties. Appl Phys A. 2005;80:1725-8.

70. Araki K, Tanaka T. Piezoelectric and elastic properties of single crystalline Se-Te alloys. Jpn J Appl Phys. 1972;11(4):472.

71. Tangney P, Fahy S. Density-functional theory approach to ultrafast laser excitation of semiconductors: application to the A1 phonon in tellurium. Phys Rev B. 2002;14:279.

72. Suchand Sandeep CS, Samal AK, Pradeep T, Philip R. Optical limiting properties of Te and Ag2Te nanowires. Chem Phys Lett. 2010;485:326-30.
73. Sharma YC, Purohit A. Tellurium based thermoelectric materials: new directions and prospects. J Integr Sci Technol. 2016;4(1):29-32.

74. Panahi-Kalamuei M, Mousavi-Kamazani M, Salavati-Niasari M. Facile hydrothermal synthesis of tellurium nanostructures for solar cells. JNS 2014:4:459-65.

75. Tsiulyanua D, Marian S, Miron V, Liess HD. High sensitive tellurium based NO2 gas sensor. Sens Actuators B. 2001;73:35-9.

76. Baghchesara MA, Yousefi R, Cheraghizadec M, Jamali-Sheinid F, Saáedi A, Mahmmoudiane MR. A simple method to fabricate an NIR detector by PbTe nanowires in a large scale. Mater Res Bull. 2016;77:131-7.

77. Huang W, Wu H, Li X, Chen T. Facile one-pot synthesis of tellurium nanorods as antioxidant and anticancer agents. Chem Asian J. 2016:11:2301-11.

\section{Submit your next manuscript to BioMed Central and we will help you at every step:}

- We accept pre-submission inquiries

- Our selector tool helps you to find the most relevant journal

- We provide round the clock customer support

- Convenient online submission

- Thorough peer review

- Inclusion in PubMed and all major indexing services

- Maximum visibility for your research

Submit your manuscript at www.biomedcentral com/submit 